\title{
PENINGKATKAN HASIL BELAJAR MATEMATIKA SISWA KELAS 4 SD MELALUI MODEL PEMBELAJARAN PROBLEM BASED LEARNING
}

\author{
Mita Puspita $^{1}$, Slameto $^{2}$, Eunice Widyanti Setyaningtyas ${ }^{3}$ \\ ${ }^{1}$ Program Studi Pendidikan Guru Sekolah Dasar, Universitas Kristen Satya Wacana Salatiga, 292014232@Student.uksw.edu \\ 2 Program Studi Pendidikan Guru Sekolah Dasar, Universitas Kristen Satya Wacana Salatiga, slameto@staff.uksw.edu \\ 3 Program Studi Pendidikan Guru Sekolah Dasar, Universitas Kristen Satya Wacana Salatiga, eunice.widyanti@gmail.com
}

\begin{tabular}{l} 
INFO ARTIKEL \\
\hline Riwayat Artikel: \\
Diterima: 21-04-2018 \\
Disetujui: 30-04-2018 \\
\hline Kata Kunci: \\
Model Pembelajaran, \\
Problem Based Learning, \\
Hasil Belajar, \\
SD, \\
Matematika
\end{tabular}

\section{A. LATAR BELAKANG}

Matematika adalah suatu ilmu yang dapat mengembangkan dan mempelajari bagaimana cara berfikir siswa. Suriasumantri (2009) "matematika adalah berfikir dengan menggunakan cara yang logis", artinya matematika adalah langkah yang dipakai untuk berpikir secara logis. Matematika sangatlah penting untuk dipelajari karena pada kehidupan sehari-hari kita menggunakan ilmu matematika. Dengan belajar matematika maka penalaran dan otak kita akan bekerja dengan baik, jadi lebih mudah untuk menerima pembelajaran yang lainnya. Dalam pembelajaran matematika hampir semua Kompetensi Dasar memerluhkan pemecahan masalah (Ismiyati, 2016), oleh sebab itu, pembelajaran matematika ini dianggap sulit dan ditakuti oleh banyak siswa. Kebanyakan siswa belajar matematika seakan akan hanya asal-asalan saja, dan mereka tidak memikirkan untuk mendapatkan nilai yang terbaik.Pada kenyataanya pembelajaran matematika di SDN 1 Tegalrejo sudah berjalan dengan baik, namun terdapat beberapa permasalahan selama proses kegiatan belajar mengajar, hal tersebut terbukti karena belum tercapainya tujuan yang diharapkan pada hasil belajar siswa khususnya mata pelajaran matematika.

Tujuan hasil belajar siswa yang mencapai KKM dapat diketahui melalui tes selama pembelajaran berlangsung. Ketika penulis melakukan observasi dan wawancara terhadap guru kelas diperoleh hasil bahwa siswa kelas 4 SDN Tegalrejo 1 tidak semua siswa mencapai Kriteria Ketuntasan Minimal $(\mathrm{KKM}) \geq 70$. Pada hasil observasi diperoleh hasil dari 16 siswa, yang mendapat nilai di atas Kriteria Ketuntasan Minimal (KKM) hanya 5 siswa atau 31,25\%, sedangkan siswa yang belum mencapai KKM 11 siswa atau 68,75\%. Dari hasil tersebut maka hasil belajar matematika di kelas 4 SDN 1 Tegalrejo masih belum mencapai tujuan yang diharapkan, dan siswa juga masih cenderung pasif.

Pembelajaran matematika akan berkembang dengan baik apabila ada metode dan aktivatas yang mendukung jalannya pembelajaran agar mendapat hasil yang terbaik dan menambah ilmu pengetahuan khususnya mata pelajaran matematika. Guru sebagai tenaga pendidik dalam pembelajaran harus aktif dan juga harus menunjang keberhasilan siswa. Karena hasil dari belajar siswa dapat berpengaruh juga dari kesesuaian seorang pendidik dalam menggunakan metode dan model pembelajaran (Rahmadani,2007). Maka dari itu guru 
harus menggunakan model pembelajaran yang menyenangkan dan dapat menarik perhatian peserta didik. Model pembelajaran yang dipakai ini mempunyai tujuan agar dapat mencapai hasil yang diharapkan.

Salah satu cara yang digunakan agar dapat meningkatkan hasil belajar siswa yaitu dengan menerapkan model pembelajaran yang dapat menarik siswa untuk beraktivitas dalam pembelajaran. Model pembelajaran yang dapat meningkatkan hasil belajar adalah model pembelajaran Problem Based Learning (PBL) (Rahmadani,2007). Slameto (2011) mendefinisikan Model Problem Based Learning (PBL) adalah salah satu model pembelajaran yang dapat menuntun dan mengembangkan kemampuan siswa agar dapat menyelesaikan permasalahan yang berorientasi pada masalah otentik dari kehidupan aktual siswa, agar dapat merangsang kemampuan berfikir secara kritis. Jadi untuk meningkatkan hasil belajar siswa dan mengasah keterampilan berpikir siswa peneliti menggunakan model pembelajaran Problem Besed Learning $(P B L)$.

\section{B. METODE PENELITIAN}

Penelitian ini adalah bentuk penelitian tindakan kelas yang bertujuan untuk meningkatkan hasil belajar siswa. Penelitian tindakan kelas (PTK) adalah penelitian yang dilakukan oleh guru yang memiliki tujuan untuk mengembangkan karakteristik dan tugas seorang guru khususnya dalam proses pembelajaran. Model yang digunakan dalam penelitian ini adalah model Kemmis dan Mc Taggart (2014:19). Kemmis dan Mc Taggart (2014:19) mendefinisikan bahwa dalam penelitian ini dilaksanakan melalui 2 siklus yang terdiri dari 3 langkan yaitu perencanaan tindakan (planning), pelaksanaan tindakan (acting) dan observasi (observasing), serta refleksi (reflecting).

Subjek pada penelitian ini yaitu siswa kelas 4 SDN 1 Tegalrejo dengan jumlah siswa 16 terdiri dari 8 siswa laki-laki dan 8 siswa perempuan. Penelitian ini dilaksanakan mulai dari tanggal 20 Februari 2018 sampai dengan 6 Maret 2018 di kelas 4 SDN 1 Tegalrejo, kecamatan Ngadirejo, Kabupaten Temanggung.

Penelitian ini berfungsi untuk mengetahui keberhasilan belajar siswa, maka peneliti melakukan tes pada tiap siklus. Siswa dikatakan berhasil jika hasil tes yang diperoleh sudah mencapai 3 indikator diantaranya: 1) Proses kegiatan belajar mengajar menggunakan model pembelajaran Problem Based Learning (PBL) terjadi peningkatan hasil belajar sebesar $\geq 75 \%$, 2) Penelitian ini dikatakan berhasil jika memperoleh persentase klasikal $\geq 75 \%$, 3) dikatakan berhasil apabila pembelajaran matematika di SDN 1 Tegalrejo hasil tes evaluasi mencapai sama dengan $\geq 75 \%$.

\section{HASIL DAN PEMBAHASAN}

\section{Hasil}

Penelitian ini diawali dengan observasi dan wawancara oleh guru kelas hal ini bertujuan untuk mengetahui permasalahan yang terjadi pada poses pembelajaran. Pada tahap awal penulis melakukan wawancara oleh guru kelas dan melihat perolehan hasil belajar siswa saat Ulangan Tengah Semester kelas 4 SD untuk dapat mengetahui permasalahan belum tercapainya tujuan hasil belajar siswa. Hasil belajar yang diperoleh siswa kelas 4 SD rata-rata 62 dengan jumlah siswa yang mencapai KKM 5 siswa atau $31,25 \%$, dan siswa yang belum mencapai KKM berjumlah 11 siswa atau $68,75 \%$. Mengacu pada nilai Kriteria Ketuntasan Minimal pada kondisi awal dapat dilihat pada tabel 1

TABEL 1

PERSENTASE KETUNTASAN HASIL BELAJAR MATEMATIKA KONDISI AWAL

\begin{tabular}{|c|c|c|c|c|}
\hline \multirow{2}{*}{} & \multirow{2}{*}{ Nilai } & \multicolumn{2}{|c|}{ Sebelum Tindakan } & \multirow{2}{*}{ Keterangan } \\
\cline { 3 - 4 } & & $\begin{array}{c}\text { Jumlah } \\
\text { Siswa }\end{array}$ & $\begin{array}{c}\text { Persent } \\
\text { ase \% }\end{array}$ & \\
\hline 1 & $\geq 70$ & 5 & $31,25 \%$ & Tuntas \\
\hline 2 & $<70$ & 11 & $68,75 \%$ & Belum Tuntas \\
\hline \multicolumn{2}{|c|}{ Jumlah } & 16 & & \\
\hline \multicolumn{2}{|c|}{ Rata-rata } & 62 & & \\
\hline Nilai Tertinggi & 84 & & \\
\hline Nilai Terendah & 40 & & \\
\hline
\end{tabular}

Berdasarkan tabel pada kondisi awal menunjukkan 11 siswa pada pembelajaran matematika kelas 4 SD belum mencapai hasil yang diharapkan, oleh karena itu penulis akan mengadakan perbaikan hasil belajar siswa dengan menggunakan model pembelajaran Problem Based Learning ( $P B L$ ) yang dilakukan dalam dua siklus. Materi yang akan diajarkan pada siklus 1 dan 2 yaitu materi Garis dan sudut dikarenakan materi ini sama sekali belum diajarkan oleh guru kelasnya.

Pelaksanaan tindakan pada siklus 1 dan 2 dengan menggunakan model pembelajaran Problem Based Learning ( $P B L$ ) pada mata pelajaran matematika dilaksanakan dalam 3 kali pertemuan dalam tiap siklus. Dibawah ini peneliti akan membahas tahapan pelaksanaan pembelajaran dengan model pembelajaran Problem Based Learning (PBL) yaitu antara lain:

\section{Perencanaan (Planning)}

Kegiatan perencanaan yang dilakukan oleh penulis yaitu penulis mencari permasalahan yang terjadi di kelas 4 pada mata pelajaran matematika dan mencari solusi untuk memecahkan permasalahanya. Selanjutnya penulis dan guru kelas membuat kesepakatan materi yang akan diajarkan dengan menggunakan model pembelajaran Problem Based Learning (PBL) sesuai dengan promes yang 
diajarkan di SD, penulis menetapkan indikator hasil materi garis dan sudut dengan mengacu pada kompetensi dasar. Peneliti menyusun Rencana Pelaksanaan Pembelajaran dengan model pembelajaran Problem Based Learning (PBL) yang kemudian di konsultasikan kepada guru kelas. Penulis menyiapkan keperluan yang akan digunakan dalam penelitian seperti lembar kegiatan guru dan siswa sesuai dengan model pembelajaran Problem Based Learning ( $P B L)$, menyiapkan media dan alat yang akan diajarkan, menyiapkan lembar kerja, menyiapkan soal tes evaluasi siswa, membuat format penilaian yang akan digunakan dalam penelitian dan juga menyusun instrumen data yang akan digunakan.

\section{Pelaksanaan Tindakan (Acting)}

Pada pelaksanaan tindakan penulis menggunakan model pembelajaran Problem Based Learning ( $P B L$ ) dengan menyesuaikan pada RPP yang dilaksanakan sebanyak 3 kali pertemuan pada tiap siklus, dengan alokasi waktu 3 x 35 menit dengan diikuti oleh semua kelas 4 SDN 1 Tegalrejo.

Pada siklus pertama penulis membahas tentang garis, sedangkan siklus kedua membahas tentang sudut. Pada awal kegiatan guru mengucapkan salam, berdoa bersama-sama dan guru mengecek kehadiran siswa. Siswa dan guru secara bersama-sama menyanyikan lagu Indonesia raya untuk menumbuhkan karakter bangsa, guru melakukan apersepsi dengan menanya pembelajaran yang sebelumnya Guru juga melakukan apersepsi dengan menyebutkan contoh-contoh garis dalam kahidupan sehari-hari. Selanjutnya guru menyampaikan tujuan pembelajaran.

Kegiatan inti dalam proses belajar mengajar ini guru menjelaskan materi siswa memperhatikan penjelasan yang disampaikan oleh guru, siswa yang belum paham diberikan kesempatan untuk bertanya. Selanjutnya guru membagi siswa ke dalam 4 kelompok, siswa diminta guru untuk berkelompok, guru sebagai tenaga pembimbing menuntun jalannya diskusi. Setelah selesai berdiskusi siswa diminta untuk mempersentasikan hasil kerja samanya, sedangkan kelompok lain diminta untuk memperhatikan dan memberikan pertanyaan.

Pada kegiatan akhir guru memberikan penguatan terhadap jawaban siswa dan memberikan contoh nyata. Guru melakukan evaluasi hasil belajar dengan bertanya mengenai pemahaman materi yang telah disampaikan oleh guru. Guru menyampaikan pembelajaran yang akan dipelajari pada pertemuan berikutnya.guru memberikan tindak lanjut dan memberikan pesan moral. Guru mengakhiri pembelajaran dengan salam.

Pelaksanaan tindakan tersebut dilaksanakan 2 kali pertemuan pada siklus 1 dan siklus 2. Sedangkan untuk pertemuan yang ke tiga siklus 1 dan siklus 2, pada kegiatan awal guru mengucapkan salam dan menanyakan kabar siswa, berdoa bersama-sama siswa kemudian mengecek kehadiran siswa. Guru mengecek kesiapan siswa dengan mengisi permainan yang telah dipersiapkan oleh guru. Kegiatan selanjutnya guru melakukan tanya jawab kepada siswa apakah ada yang ingin ditanyakan tentang materi yang sudah diajarkan, kemudian guru mengulas kembali tentang materi yang sudah diajarkan. Guru memberikan tindak lanjut atas materi ajar yang telah dipelajari selama dua kali pertemuan berupa tes. Siswa mengerjakan tes secara mandiri.Guru menyampaikan rencana pembelajaran yang akan datang. Guru mengingatkan siswa untuk belajar dengan giat dan mengulang materi yang telah diajarkan. Guru mengucapkan salam penutup dan siswa menjawab.

\section{Observasi (Observing)}

Proses kegiatan belajar mengajar dengan menggunakan model pembelajaran Problem Based Learning (PBL) dinilai dan diamati observer. Berdasarkan hasil observasi kegiatan guru dan siswa pembelajaran matematika di kelas 4 SD dengan model pembelajaran Problem Based Learning (PBL) sudah terlaksana sesuai dengan kegiatan pembelajaran yang tersusun pada Rencana Pelaksanaan Pembelajaran dan pada lembar observasi guru dan siswa. Agar kita dapat mengetahui terjadinya peningkatan hasil belajar siswa kelas $4 \mathrm{SD}$ dilakukan tes pada tiap siklus, jika kegiatan refleksi sudah sesuai dengan indikator keberhasilan maka penelitian tersebut dikatakan berhasil.

\section{Refleksi (Reflecting)}

Kegiatan Refleksi memiliki tujuan untuk mengetahui tingkat keberhasilan siswa selama proses pembelajaran. Dengan kegiatan refleksi ini, siswa dan guru dapat mengetahui fungsi dari model pembelajaran Problem Based Learning (PBL). Dengan menerapkan model pembelajaran Problem Based Learning (PBL) seorang pendidik akan mendapatkan pengetahuan baru karena model ini dapat menarik perhatian peserta didik. Guru juga akan lebih mudah dalam mengajar sehingga pembelajaran akan lebih efektif dan efisien, karena model pembelajaran ini membantu siswa untuk lebih aktif dalam proses belajar mengajar di kelas. Selain itu membantu kesempatan pendidik untuk mengajarkan peserta didik tentang belajar berkelompok untuk melakukan kerja sama mengerjakan sustu permasalahan. Bagi peserta didik, dengan model pembelajaran Problem Based Learning (PBL) peserta didik akan merasa lebih tertarik dan mudah untuk memahami materi ajar, karena peserta didik diberikan contoh yang berkaitan dengan kehidupan sehari. Dalam pembelajaran siswa 
merasa aktif dan tidak bosan karena dalam pembelajaran berprinsip kerja kelompok dengan teman.Untuk mengetahui tingkat keberhasilan pembelajaran antara kondisi awal dan siklus I dan siklus 2 dengan model pembelajaran Problem Based Learning (PBL), dapat dicermati pada tabel 2 berikut ini :

TABEL 2

PERBANDINGAN KETUNTASAN HASIL BELAJAR MATEMATIKA

PRA SIKLUS, SIKLUS I, DAN SIKLUS II

\begin{tabular}{|c|c|c|c|c|c|c|c|}
\hline \multirow[b]{2}{*}{ No } & \multirow[b]{2}{*}{ Nilai } & \multicolumn{2}{|c|}{ Kondisi awal } & \multicolumn{2}{|c|}{$\begin{array}{r}\text { Siklus } 1 \\
\end{array}$} & \multicolumn{2}{|c|}{$\begin{array}{r}\text { Siklus } 2 \\
\end{array}$} \\
\hline & & $\begin{array}{c}\text { Jumlah } \\
\text { siswa }\end{array}$ & Persentase \% & $\begin{array}{c}\text { Jumlah } \\
\text { siswa }\end{array}$ & Persentase \% & $\begin{array}{c}\text { Jumlah } \\
\text { siswa }\end{array}$ & Persentase \% \\
\hline 1 & Tuntas & 5 & $31,25 \%$ & 11 & $75 \%$ & 15 & $93,75 \%$ \\
\hline 2 & Belum Tuntas & 11 & $68,75 \%$ & 4 & $25 \%$ & 1 & $6,25 \%$ \\
\hline & Jumlah & 16 & $100 \%$ & 16 & $100 \%$ & 16 & $100 \%$ \\
\hline & Rata-rata & 62 & & 77,37 & & 83 & \\
\hline & ilai Tertinggi & 84 & & 98 & & 58 & \\
\hline & lai Terendah & 40 & & 40 & & 96 & \\
\hline
\end{tabular}

Dalam pembelajaran siklus I dan siklus 2 terlihat nilai siswa membaik dari kondisi awal, siswa merasa lebih aktif dan tertarik dalam proses pembelajaran, karena belajar dengan keadaan yang berbeda dari sebelumnya yaitu dengan model pembelajaran Problem Based Learning (PBL). Pembelajaran dengan model pembelajaran ini diharuskan siswa untuk aktif dan berfikir kritis dalam pembelajaran. Selain itu pembelajaran ini menekankan kerja kelompok dan bekerja sama saling membantu dan membutuhkan dalam memecahkan suatu masalah sehingga dalam satu kelompok belajar siswa harus saling memahami apa yang mereka bahas sehingga dalam satu kelompok siswa tau apa yang mereka pelajari. Sehingga pada tahapan tes pada tiap siklus siswa merasa terbantu pada saat langkah langkah pembelajaran berlangsung, karena siswa belajar dengan cara yang menyenangkan, yaitu dengan cara kerja kelompok untuk membahas materi ajar. Oleh karena itu siswa yang tidak tau akan menjadi tau karena dalam kelompok setiap siswa wajib berperan secara aktif.

\section{Pembahasan}

Sebelum melakukan penelitian, hasil belajar matematika (pra siklus) siswa kelas 4 SDN 1 Tegalrejo masih belum mencapai tujuan hasil pembelajaran yang diharapkan. Pada kondisi awal siswa yang mendapatkan nilai tuntas dalam pembelajaran matematika hanya 5 siswa $31,25 \%$, sedangkan siswa yang belum tuntas dalam pembelajaran berjumlah 11 siswa 68,75 \%. Dengan nilai rata-rata siswa 62 , untuk nilai tertinggi 84 , dan terendah 40. Pada tes siklus I berjumlah 12 siswa tuntas dengan persentase $75 \%$. Siswa yang belum tuntas dalam proses penelitian berjumlah 4 siswa dengan persentase $25 \%$. Dengan nilai rata rata siswa 77,37 nilai tertinggi 98 dan nilai terendah 40. Sedangkan siklus II terjadi peningkatan hasil belajar, hasil dari tes tingkat kelulusan berjumlah 15 siswa atau $93,75 \%$, dan siswa yang tidak tuntas KKM adalah 1 atau 6,25\% dengan rata-rata nilai siswa 83 nilai tertinggi 96 dan nilai terendah 58 .

Hasil penelitian ini juga sejalan dengan penelitian yang dilakukan oleh Febriana, Afifah (2010), Sukarman (2012), dan Rizka Vitasari (2013) Penelitian tersebut berhasil menerapkan model pembelajaran Problem Based Learning (PBL) berturut pada mata pelajaran matematika kelas IV SDN Kauman Lor 01 Kecamata Pabelan Kabupaten Semarang, pada siswa kelas 4 SD Negeri Batiombo 02 Kecamatan Bandar Kabupaten Batang Semester 2/2011-2012 dan pada siswa kelas V SD Negeri 5 Kutosari.Ketiga penelitian tersebut menyimpulkan bahwa model pembelajaran Problem Based Learning $(P B L)$ dapat meningkatkan hasil belajar matematika siswa.

Tujuan diterapkannya model pembelajaran Problem Based Learning (PBL) adalah dapat meningkatkan hasil belajar siswa. Melalui model ini siswa dapat menciptakan pengetahuan dan keterampilan siswa agar dapat berpikir logis terhadap ide-ide dalam memecahkan suatu permasalahan (Trianto, 2013:94-96). Hal ini terbukti dengan diterapkanya model pembelajaran Problem Based Learning $(P B L)$ siswa menjadi lebih paham ketika guru menjelaskan materi pembelajaran, pembelajaran yang terjadi di kelas menjadikan siswa untuk lebih aktif dan menyenangkan, mendorong siswa agar berfikir lebih kritis, saat bekerja dengan kelompoknya terjadi kerja sama yang kompak antar anggota kelompoknya, dengan disajikan suatu permasalahan maka siswa dapat memecahkan masalah sendiri dengan pengetahuan yang relevan dan melatih mereka untuk cakap dalam suatu pembelajaran, serta dengan menyajikan hasil karya siswa dapat melatih tanggung jawab terhadap jawaban atau pertanyaan siswa lain (Smith dalam Amir, 2009:27-29). Keunggulan model pembelajaran Problem Based Learning (PBL) ini yaitu antara lain: 1). siswa dapat memahami materi yang guru ajarkan, 2) menjadikan siswa lebih aktif dalam berpikir dan bertindak, 3)pembelajaran yang diajarkan akan lebih 
bermakna, 4) siswa akan menjadi lebih mandiri dan tanggung jawab, dan 5) akan menumbuhnya interaksi sesama teman (Ibrahim \& Nur dalam Agus N. Cahyo, 2013:285-287)

Setelah dilakukan penelitian mulai dari kondisi awal, siklus I sampai dengan siklus 2 dalam penelitian tindakan kelas ini menunjukkan bahwa ada peningkatan hasil belajar siswa dan siswa dapat mencapai KKM yang telah ditetapkan. Peningkatan tersebut terjadi setelah diterapkannya model pembelajaran Problem Based Learning (PBL) pada mata pelajaran matematika materi garis dan sudut. Perolehan nilai hasil belajar pada kelas 4 SD meningkat dari mulai prasiklus 62, siklus 1 menjadi 77,37 dan siklus 2 terjadi peningkatan yaitu 83. Dari data yang diperoleh dari hasil tes pada penelitian tersebut dapat dikatakan mengalami peningkatan yang sangat baik dibandingan dengan sebelum diterapkanya model pembelajaran Problem Based Learning $(P B L)$

\section{SIMPULAN DAN SARAN}

\section{Simpulan}

Berdasarkan hasil penelitian dan pembahasan dapat disimpulkan bahwa pembelajaran Matematika dengan model pembelajaran Problem Based Learning ( $P B L$ ) dapat meningkatkan hasil belajar Matematika siswa kelas IV SDN 1 Tegalrejo. Hal ini ditandai dengan meningkatnya nilai rata-rata hasil belajar siswa, dapat terlihat dari hasil tes akhir pada setiap siklus.Sebelum dilakukan model pembelajaran Problem Based Learning (PBL) atau pra-siklus nilai rata rata nilai kelas IV SDN 1 Tegalrejo Kecamatan Ngadirejo, Kabupaten Temanggung tahun ajaran 2017/2018 yang telah mencapai KKM 70 adalah 5 siswa dengan persentase $31,25 \%$. Siswa yang belum mencapai KKM berjumlah 11 anak atau $68,75 \%$. Dengan perolehan nilai tertinggi 84 dan nilai terendah 40. Dengan model pembelajaran Problem Based Learning (PBL) pada siklus I kelas IV SDN 1 Tegalrejo, Kecamatan Ngadirejo Kabupaten Temanggung, hasil nilai tes siklus I berjumlah 12 siswa dengan persentase $75 \%$ mencapai KKM 70. Siswa yang belum tuntas berjumlah 4 orang siswa dengan persentase $25 \%$. Dengan nilai rata-rata siswa 77,37 nilai tertinggi 98 dan nilai terendah 40. Pada siklus II nilai kelas IV SDN 1 Tegalrejo Kecamatan Ngadirejo, Kabupaten Temanggung. Tingkat kelulusan KKM berjumlah 15 atau 93,75\%. Siswa yang belum tuntas 1 anak atau $6,25 \%$. Dengan nilai rata-rata siswa 83 nilai tertinggi 96 dan nilai terendah 58 .

Indikator keberhasilan dari penelitian ini adalah apabila ada peningkatan yaitu ketuntasan hasil belajar siswa mencapai $75 \%$ dari jumlah siswa yang ada dikelas. Pada siklus II ketuntasan belajar mencapai 93,75\%, maka pembelajaran dengan model pembelajaran Problem Based Learning (PBL) dapat meningkatkan hasil belajar siswa

\section{Saran}

a. Bagi Siswa. Penulis menyarankan supaya siswa lebih aktif dalam proses kegiatan pembelajaran dan dapat bekerjasama dengan kelompoknya dengan penuh tanggung jawab. Siswa juga harus bisa meningkatkan kemampuan dalam penyelesaian masalah nyata dalam kehidupan sehari-hari.

b. Bagi Guru. Guru dapat menggunakan model pembelajaran Problem Based Learning (PBL) sebagai salah satu model pembelajaran yang dapat meningkatkan hasil pembelajaran matematika, karena dengan model pembelajaran Problem Based Learning (PBL) siswa akan lebih semangat dan lebih aktif dalam proses pembelajaran. Pembelajaran dengan model Problem Based Learning, hendaknya dikemas dalam pembelajaran yang menyenangkan sesuai dengan karakter siswa.

\section{UCAPAN TERIMA KASIH}

Terima kasih penulis sampaikan kepada semua pihak yang telah membantu dalam proses penelitian diantaranya adalah (1) Alimah, S.Pd., Kepala SDN 1 yang telah memberikan izin untuk melakukan penelitian pada tugas akhir ini, (2) Muayanah, S.Pd., wali kelas 4 SDN 1 Tegalrejo yang telah memberikan izin untuk melakukan penelitian dan observasi proses pembelajaran dalam penelitian, (3) Siswa-siswi kelas 4 SDN 1 Tegalrejo yang bersedia menjadi objek dalam penelitian dan berpartisipasi aktif selama penelitian skripsi ini berlangsung.

\section{DAFTAR RUJUKAN}

[1] Ahmad Susanto, M. P. (2016). Teori belajar dan pembelajaran di sekolah dasar. Jakarta: Kencana.

[2] Amir, Taufik. 2009. Inovasi Pendidikan Melalui Problem Based Learning. Jakarta: Kencana

[3] Dimyati, Mudjiono. 2006. Belajar dan Pembelajaran. Jakarta: PT Rineka Cipta.

[4] Fadlillah, M. (2016). Edutainment Pendidikan Anak Usia Dini: Menciptakan Pembelajaran Menarik, Kreatif dan Menyenangkan. Prenada Media

[5] Ismiyati. (2016). Peningkatan Hasil Belajar Matematika melalui Model Pembelajaran Problem Based Learning pada Siswa Kelas V SD Negeri Kauman Kidul Salatiga Semester 1 Tahun Pelajaran 2015/2016

[6] Rahmadani, N., \& Anugraheni, I. (2017). Peningkatan Aktivitas Belajar Matematika Melalui Pendekatan Problem Based Learning Bagi Siswa Kelas 4 Sd. Scholaria: Jurnal Pendidikan Dan Kebudayaan, 7(3), 241-250.

[7] Rahman, A. (2013). Penerapan Metode Snowball Throwing Untuk Meningkatkan Hasil Belajar IPS Siswa 
Kelas V Pada SDN No. 1 Pantolobete. Jurnal Kreatif Tadulako Online, 5(4).

[8] Riyanto, yatim. 2010. Paradigma baru pembelajaran. Jakarta: Kencana Prenada Media Group.

[9] Rusman. 2013. Model-Model Pembelajaran. Jakarta: PT Rajagrafindo persada.

[10] Slameto. 2011. Penelitian dan Inovasi Pendidikan. Semarang:Widya Sari Press

[11] Suriasumantri, J. S. 2009. Filsafat Ilmu Sebuah Pengantar Populer. Jakarta: Pustaka Sinar Harapan.

[12] Triyanto. 2011. Model-model Pembelajaran Inovatif. Jakarta: Prestasi Pustaka.

[13] Wardani, Naniek Sulistya, dkk. 2010. Asesmen Pembelajaran SD. Salatiga : Widya Sari Press.

\section{Biografi Penulis Utama}

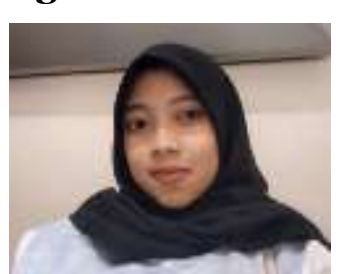

Penulis bernama lengkap Mita Puspita lahir di Temanggung pada tanggal 3 Maret 1996 dari pasangan Hudiman dan Suamin. Penulis adalah anak kedua dari tiga bersaudara. Penulis menempuh pendidikan dasar di SDN 1 Tegalrejo, Kecamatan Ngadirejo, Kabupaten Temanggung. Selanjutnya menempuh pendidikan di SMP Negeri 1 Ngadirejo, Kabupaten Temanggung dan terakhir di SMA Negeri 1 Candiroto. Kemudian penulis melanjutkan pendidikan di Perguruan Tinggi mengambil jurusan S1 Pendidikan Guru Sekolah Dasar (PGSD), Fakultas Keguruan dan Ilmu Pendidikan (FKIP) Universitas Kristen Satya Wacana Salatiga pada tahun 2014 sampai sekarang. Apabila ada kritik dan saran dapat dikirim lewat email penulis di:292014232@student.uksw.edu 